\title{
Review
}

\section{Modulation of Immune Functions by Foods}

\section{Shuichi Kaminogawa ${ }^{1}$ and Masanobu Nanno ${ }^{2}$}

\author{
${ }^{1}$ Department of Food Science and Technology, College of Bioresource Sciences, Nihon University and ${ }^{2}$ Yakult \\ Central Institute for Microbiological Research, Japan
}

\begin{abstract}
Evidence is rapidly accumulating as to the beneficial effects of foods. However, it is not always clear whether the information is based on data evaluated impartially in a scientific fashion. Human research into whether foods modulate immune functions in either intervention studies or randomized controlled trials can be classified into three categories according to the physical state of subjects enrolled for investigation: (i) studies examining the effect of foods in healthy individuals; (ii) studies analyzing the effect of foods on patients with hypersensitivity; and (iii) studies checking the effect of foods on immunocompromized subjects, including patients who had undergone surgical resection of cancer and newborns. The systematization of reported studies has made it reasonable to conclude that foods are able to modulate immune functions manifesting as either innate immunity (phagocytic activity, NK cell activity) or acquired immunity (T cell response, antibody production). Moreover, improvement of immune functions by foods can normalize the physical state of allergic patients or cancer patients, and may reduce the risk of diseases in healthy individuals. Therefore, it is valuable to assess the immune-modulating abilities of foods by measuring at least one parameter of either innate or acquired immunity.
\end{abstract}

Keywords: amino acid - fatty acid - lactic acid bacteria - mineral - oligosaccharide - polyphenol vitamin

\section{Introduction}

Foods contain various substances that can control the physiological functions of the body, and modulating immune responses is one of the most important functions of foods. Immune functions are indispensable for defending the body against attack by pathogens or cancer cells, and thus play a pivotal role in the maintenance of health. However, the immune functions are disturbed by malnutrition, aging, physical and mental stress or undesirable lifestyle. Therefore, the ingestion of foods with immune-modulating activities is considered an efficient way to prevent immune functions from declining and reduce the risk of infection or cancer.

In order to establish a diet capable of preserving immune functions, it is necessary to search and systematize reliable

For reprints and all correspondence: Shuichi Kaminogawa, Department of Food Science and Technology, College of Bioresource Sciences, Nihon

University, 1866 Kameino, Fujisawa-shi, Kanagawa 252-8510, Japan.

Tel: +81-466-84-3983; Fax +81-466-84-3983;

E-mail: masanobu-nanno@yakult.co.jp results on the immune-modulating effects of food-derived substances. To this end, we have selected reports that evaluated the immune-modulating abilities of foods in an intervention study or a randomized controlled trial. Thereafter, we classified these studies according to the physical state of their subjects into three categories: (i) studies examining immune parameters of healthy individuals whose immune functions are poorer than expected; (ii) studies analyzing immune parameters of patients with hypersensitivity; and (iii) studies checking immune parameters of immunocompromized subjects, including patients who had undergone surgical resection of cancer and newborns. We found that the measurement of at least one parameter representing either innate or acquired immunity was useful for evaluating the immune-modulating abilities of foods. This review summarizes the immune-modulating characteristics of foods that have been verified in human as well as animal studies. In addition, we briefly describe the pathways by which food-derived substances are absorbed into the body and the mechanisms through which food-derived substances exert their immunemodulating effects.

The online version of this article has been published under an open access model. Users are entitled to use, reproduce, disseminate, or display the open access version of this article provided that: the original authorship is properly and fully attributed; the Journal and Oxford University Press are attributed as the original place of publication with the correct citation details given; if an article is subsequently reproduced or disseminated not in its entirety but only in part or as a derivative work this must be clearly indicated. 


\section{Intestinal Transport of Foods}

Molecules found in foods can be absorbed by multiple routes. Carbohydrates, proteins and lipids are broken down into monosaccharides, amino acids and fatty acids, respectively, by diverse hydrolases secreted in the gut lumen or associated with membranes of intestinal epithelial cells (IECs). These food components are actively transported via specific carrier molecules on the surface membrane of IECs and used as nutrients (Fig. 1). Vitamins and minerals in foods are also absorbed through IECs by passive diffusion or active transport using specific carrier molecules (Fig. 1). The main role of vitamins and minerals is to regulate the various physiological functions of cells.

Indigestible macromolecules such as rigid proteins are incorporated into Peyer's patches (PPs) developing throughout the intestine (1). PPs are organized lymphoid tissues that are covered by a particular epithelial layer, the follicle-associated envelope (FAE), and composed of both follicles rich in B cells and an interfollicular area filled with antigen-presenting cells and $\mathrm{T}$ cells. Horseradish peroxidase (HRP) given orally to mice was detectable in $\mathrm{M}$ cells (microfold cells) within the FAE (2). Moreover, a study using isolated intestinal loops from piglets has revealed that the absorptive rate of HRP was higher in the intestinal segments with PPs than without (3). These results demonstrate that $\mathrm{M}$ cells in FAE are the route for efficiently incorporating indigestible proteins (Fig. 1). Macromolecules incorporated into PPs are taken by antigen-presenting cells and induce antigen-specific immune responses. On the other hand, macromolecules with higher molecular size such as carrageenan (88 $110 \mathrm{kDa}$ ) are hardly absorbed in the intestine.

Small molecules can be transported through IECs by endocytosis (Fig. 1). By contrast, food-derived substances are not usually transported between IECs (paracellular transport), because IECs closely connected by tight junctions do not usually allow food-derived substances to pass through. However, the barrier function of tight junctions is not stiff and breast milk-derived proteins can be transported without degradation between IECs in newborns (4) (Fig. 1). As the immune system in newborns is immature, it is reasonable that newborns incorporate breast milk-derived proteins including lactoferrin and maternal $\mathrm{IgG}$ to protect from infection. In contrast, dysfunction of the tight junction due to genetic defect is dangerous. Patients with food allergy have intestines with a

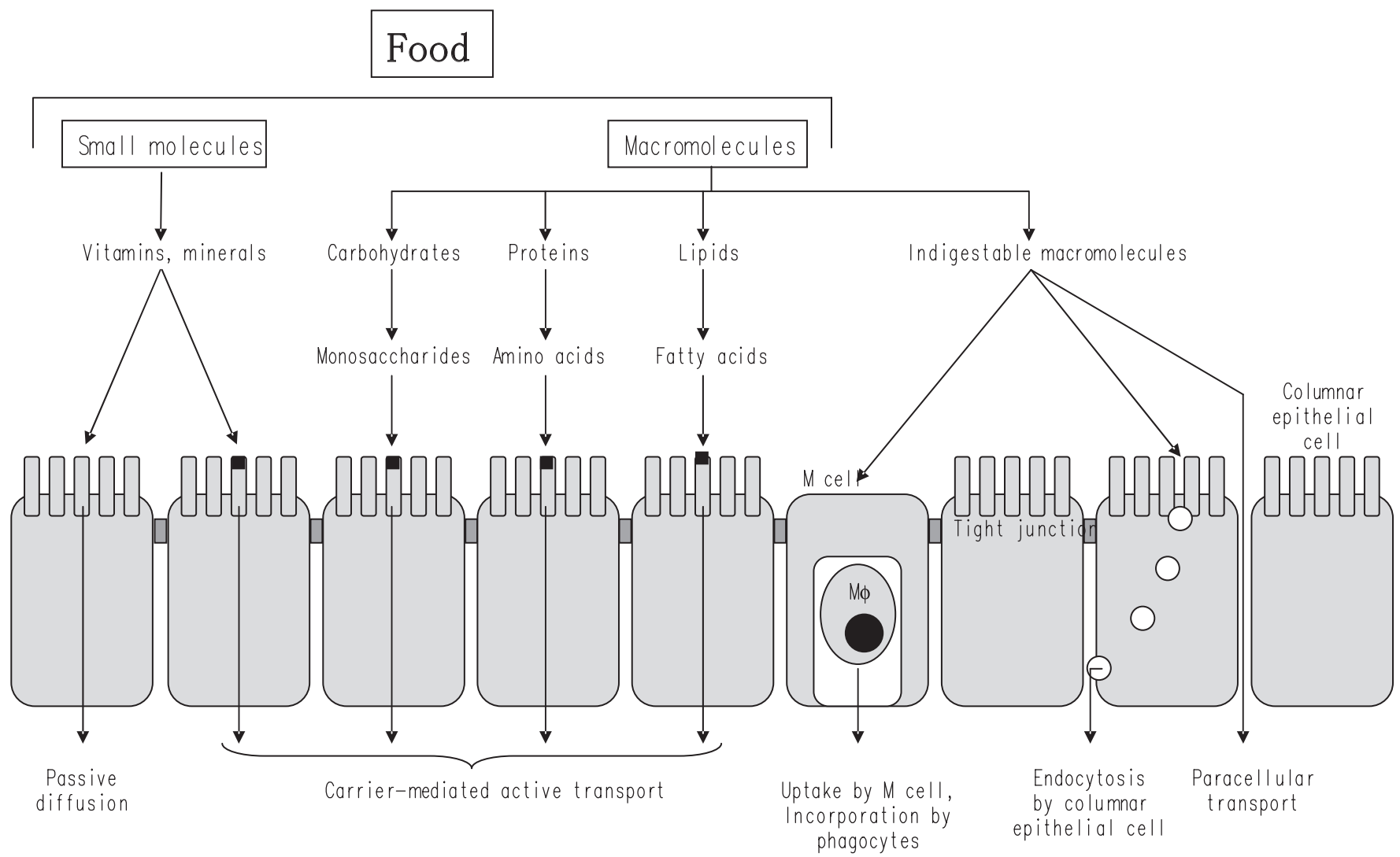

Figure 1. Mechanisms for transport of food-derived substances. Carbohydrates, proteins and lipids are digested by multiple hydrolases secreted into the gut lumen and associated with membranes of columnar epithelial cells. Specific carrier molecules transport monosaccharides, amino acids and fatty acids, and vitamins and minerals are incorporated by passive diffusion or transported by carrier proteins. In contrast, indigestable macromolecules are incorporated by M cells present in the follicle-associated envelope of Peyer's patches or through endocytosis by columnar epithelial cells. The incorporation of foods by diffusion through intercellular spaces between columnar epithelial cells does not occur except for in newborns or in subjects with a genetic deficiency in a barrier function. 
reduced barrier function, and therefore an antigenic load in the gut lumen can be easily incorporated into the body (5).

The intestine and liver are important organs in terms of supply of nutrition and self-defense, and these organs are equipped with specialized immune systems. A huge number of IgA-producing cells and intraepithelial $\mathrm{T}$ lymphocytes (IELs) with unique physiological functions are colonized in the gut and play a pivotal role in defense against pathogens (6). Moreover, natural killer (NK) T cells are enriched in liver and highly effective in the eradication of tumor cells (7). Hazardous substances (pathogens, toxins and allergens) are recognized as antigens and activate the immune system, but most gut antigenic loads (food-derived molecules and indigenous intestinal bacteria) are harmless and the immune response to these antigens is suppressed in healthy humans (oral tolerance). In contrast, the immune system of patients with inflammatory bowel disease responds excessively to the indigenous intestinal bacteria, causing inflammation in the intestine (8).

It is of great interest that some substances in foods can open tight junctions between IECs. When the capsianoside contained in a sweet pepper was added to the apical side of a monolayer formed by the human IEC line Caco-2, the tight junctions transiently opened, followed by a drop of electric resistance between the apical and basal sides (9). While the tight junction basically acts as a barrier to pathogens or toxic substances in the intestine, the transient opening of tight junctions may be so important that antigens can be captured by dendritic cells in the intestinal lamina propria and immune responses to these antigens are efficiently evoked (10).

\section{Regulation of Immune Functions by Foods}

Immune-modulating abilities of foods have been investigated in a number of human studies. We tentatively classified these researches into three categories according to the state of immune system in subjects enrolled for investigation: (i) healthy individuals; (ii) patients with hypersensitivity; and (iii) subjects in immunocompromised state.

\section{Foods Capable of Improving Immune Functions in Healthy Individuals}

Immune functions are not stable and usually fluctuate within fixed limits. In addition, various endogenous and exogenous factors can influence immune functions. Corticosteroids suppress a broad range of immune functions efficiently and exhibit anti-inflammatory activity. Malnutrition, aging, stress and undesirable lifestyle are also factors lowering immune functions. The elderly exhibit higher susceptibility to infection than the young, and delayed type hypersensitivity (DTH), antigen-specific antibody production, the proliferative response of $T$ cells and the relative proportion of $T$ cells decline with aging (11-16). Many kinds of physical and mental stress also disturb immune functions. For instance, a surgical operation exhausts patients and is accompanied by a decline in their DTH, and caregivers of dementia patients show a decrease in NK cell activity, antigen-specific antibody production and $\mathrm{T}$ cell proliferation on account of depression $(17,18)$. Moreover, NK cell activity deteriorates under not only mental stress after divorce but also physical stress of heavy exercise (19-24). It is widely known that systemic malnutrition associated with a deficiency of protein and energy causes a decline in immune functions and results in susceptibility to infection (25-28). A deficiency in vitamins and minerals induces an attenuation of immune functions including phagocytic activity, NK cell activity, DTH, antigen-specific antibody production, and the proliferative response of T cells $(29,30)$. In addition, NK cell activity and the proliferative response of $\mathrm{T}$ cells decline in patients with chronic fatigue syndrome (31).

The deterioration of immune functions possibly causes loss of health. A higher risk of infection is closely linked with low NK cell activity, and increased risk of mortality in the elderly after pathogenic infection is correlated with a decline in DTH (32-35). Bodily dysfunctions in chronic fatigue syndrome patients are negatively correlated with the proliferative response of $\mathrm{T}$ cells (36).

These findings clearly demonstrate that immune functions in healthy individuals tend to be disturbed by various factors, and deterioration of health is closely connected with dysregulation of immune functions. On the other hand, it has been proposed that food-derived components can improve the immune functions in healthy individuals. Vitamins, minerals, and fatty acids enhance DTH (37-40), vitamins and minerals enforce antigen-specific antibody production (41-45) and vitamins, minerals and oligosaccharides increase $\mathrm{T}$ cells and augment their proliferative response $(30,37,43,46-51)$. In addition, vitamins, minerals and lactic acid bacteria promote phagocytic activity and NK cell activity (30,43,52-61) (Fig. 2). The ingestion of these foods not only normalizes immune functions but also reduces the incidence of pathogenic infection $(30,41,43,62-64)$.

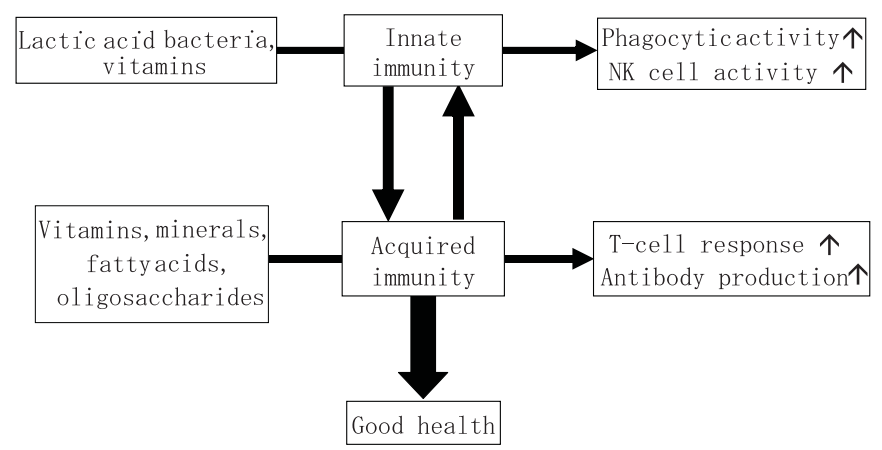

Figure 2. Modulation of immune functions by foods. The immune system is divided into innate immunity and acquired immunity, and food-derived substances can modulate either innate or acquired immunity. For example, probiotics such as lactic acid bacteria and some vitamins enhance phagocytic activity and natural killer (NK) cell activity (innate immunity), while vitamins, minerals, amino acids, fatty acids and oligosaccharides augment $\mathrm{T}$ cell responses and antibody production (acquired immunity). A balance of innate and acquired immunity is desirable for good health. 
Table 1. Parameters available for evaluating the immune-modulating effects of foods in humans

\begin{tabular}{ll}
\hline Subjects & Beneficial changes to parameters induced \\
& by ingesting foods \\
\hline Healthy individuals & Delayed type hypersensitivity $\uparrow(37-40)$, \\
& Antigen-specific antibody antibody \\
& production $\uparrow(41-45)$, \\
& Mitogen- or antigen-induced T cell \\
& proliferation and T cell number $\uparrow(46-51)$, \\
& NK cell activity and phagocytic activity $\uparrow$ \\
& (52-61) \\
Patients with hypersensitivity & Soluble CD4 level in serum $\downarrow$ (67), TNF- $\alpha$ \\
& level in feces $\downarrow$ (79), \\
& Inducible surface CD23 level $\downarrow$ (78), \\
& soluble IL-2R level in serum $\downarrow(67,78)$, \\
& Soluble VCAM level in serum $\downarrow$ (78), ECP \\
& level in feces or serum $\downarrow(67,86)$, \\
& IFN- $\gamma$ production $\uparrow(81)$, TGF- $\beta$ \\
& level $\downarrow$ (67), eosinophil number $\downarrow$ (81) \\
& Phagocytic activity $\uparrow(133)$, NK cell \\
& number $\uparrow(134,137)$, \\
T cell number and IFN- $\gamma$ level in serum $\uparrow(135)$, \\
Delayed type hypersensitivity $\uparrow(133,135)$, \\
NK cell activity $\uparrow(139)$, antigen-specific \\
antibody production $\uparrow(140)$, \\
T cell number and IgG level in serum $\uparrow(141)$ \\
\hline immubjects in & \\
\hline &
\end{tabular}

Summarizing the results reported so far, it is reasonable to conclude that the effect of foods on immune functions can be evaluated in healthy subjects by measuring either parameters concerning innate immunity (phagocytic activity and NK cell activity) or parameters concerning acquired immunity (DTH, antigen-specific antibody production, the proliferative response of $\mathrm{T}$ cells and $\mathrm{T}$ cell number) (Table 1). Therefore, despite fears that immune functions may decline due to malnutrition, aging, stress or undesirable lifestyle, one can remain healthy and reduce the risk of infection or cancer by eating foods capable of enhancing phagocytic activity, NK cell activity, DTH, antigen-specific antibody production, the proliferative response of $\mathrm{T}$ cells and/or $\mathrm{T}$ cell numbers.

\section{Foods Capable of Improving Clinical Symptoms in Patients With Hypersensitivity}

Immune reactions are usually evoked in response to externally derived hazardous antigens. However, in patients with hypersensitivity represented by immediate type allergy, immune reaction to non-toxic antigens and sometimes to the body's own molecules is induced. The causes of hypersensitivity are mainly genetic, but environmental factors, including air pollution, dietary components and residential conditions, also play an important role. As clinical condition and immune parameters change concomitantly in allergic patients, it is possible to observe the effects of foods by measuring the immune parameters associated with allergic reactions.

Generation of pro-inflammatory cytokines and chemokines and expression of cell adhesion molecules are involved in the progression of allergic diseases including atopic dermatitis, pollinosis and allergic rhinitis. Levels of pro-inflammatory cytokines and chemokines increase and the expression of cell adhesion molecules is enhanced in allergic patients (65-70). Furthermore, eosinophils as well as mast cells secrete chemical mediators and worsen the clinical symptoms in the inflammatory areas $(71,72)$. In order to establish an objective assessment of the clinical state of allergic patients, a skin test, the antigen-induced response and the SCORAD score have all been utilized $(73,74)$.

When the immune parameters representing clinical symptoms characteristic of atopic dermatitis, pollinosis and allergic rhinitis normalize, the patients recover from allergic diseases $(67,75)$. Therefore, normalization of these immune parameters by foods is helpful in that allergic patients recover their health and persons with a predisposition to allergies may avoid falling ill. Parietaria extract (76,77), herbal extract (78) and lactic acid bacteria $(67,79-89)$ have been found to suppress allergic diseases in human subjects as well as animal models.

Based on findings reported to date, we conclude that the following immune parameters can be used to evaluate the effects of foods on the clinical symptoms of allergic patients: (i) parameters to directly assess clinical symptoms in allergic patients: skin test $(75,82)$, skin-induced response (76), SCORAD score $(74,78,90)$; (ii) parameters that vary in association with the clinical symptoms of allergic patients: TNF- $\alpha$ level $(65,66,79,91)$, soluble CD4 level (67), soluble CD23 level or inducible surface CD23 level $(68,78,92)$, soluble IL-2R level $(67,68,93,94)$, soluble VCAM level $(70,78)$, amount of granular protein in eosinophils (ECP, EPX) $(67,86,95)$; (iii) parameters possibly involved in the clinical symptoms of allergic patients: $\operatorname{IgG}_{4}$ level $(75)$, IL-4/IFN- $\gamma$ production $(81,96)$, TGF- $\beta$ level $(67,97,98)$, eosinophil number $(81,99)$ (Table 1).

An allergic reaction is a sequential immune response involving the processing and presentation of the allergen, activation of allergen-specific $\mathrm{T}$ and $\mathrm{B}$ cells, production of $\operatorname{IgE}$ against the allergen, and activation of mast cells and eosinophils triggered by the allergen. Therefore, food-derived materials could prevent allergy by counteracting at least one step in the cascade of allergic reactions. It has been reported that a variety of foods contain substances able to prevent an allergic reaction (100-102).

\section{Foods Capable of Improving Immune Functions in Subjects in an Immunocompromised State}

Cancer patients are usually immunosuppressed and at high risk of infection due to a reduction of immune functions. Therefore, foods capable of enhancing the immune responses of cancer patients with disturbed immune functions are valuable.

Invading pathogenic bacteria or viruses are captured and killed by phagocytes such as neutrophils and macrophages, and NK cells recognize and lyse infected cells. Activated NK cells and $\mathrm{T}$ cells produce huge amounts of IFN- $\gamma$, which further augments the anti-bacterial activity of macrophages (103-106).

Pathogens that have escaped capture by phagocytes or NK cells are incorporated and processed by professional antigenpresenting cells, which stimulate $\mathrm{T}$ cell clones expressing 
antigen receptors specific for pathogens. Activated antigen-specific $\mathrm{T}$ cells secrete various arrays of cytokines necessary for antibody production, and pathogen-specific antibodies play an important role in the exclusion of pathogens invading the airway, intestine and urinary tract (107-109). IgA secreted in the intestinal mucosa can neutralize toxins produced by pathogens and prevents diarrhea (110), and IgG circulating in sera is principally for defense against infection in the upper respiratory tract (107).

The incidence of infection increases and the aggravation of infectious diseases occurs when innate and acquired immune functions decline or are insufficient. Patients with undetectable levels of NK cell activity suffer frequent viral infections and the transfer of NK cells into suckling mice can render the recipient mice resistant to infection for murine cytomegalovirus $(111,112)$. Patients with Gaucher disease, who were highly susceptible to serious bacterial infections, had macrophages with impaired anti-bacterial activity and the rate of infection among marrow transplant recipients 100-365 days after transplantation was negatively correlated with the total number of B cells and monocytes $(113,114)$. On the other hand, several reports have shown that the improvement of depressed immune functions by ingesting foods reduced infection rates and mitigated the severity of infectious disease $(43,115-118)$. When assessing the anti-infectious capabilities of foods, phagocytic activity, NK cell activity, T cell number, production of antigen-specific antibodies and total $\mathrm{IgG}$ level can be regarded as useful parameters.

NK cells exhibit cytotoxic activity against not only infected cells but also cancer cells (119-121). IFN- $\gamma$ produced by activated NK cells suppresses the proliferation of cancer cells and activates cytotoxic $\mathrm{T}$ cells and macrophages $(122,123)$. While NK cells kill cancer cells in an antigen non-specific manner, cytotoxic $\mathrm{T}$ cells recognize specific antigens of cancer cells for killing. Moreover, macrophages secrete molecules toxic to cancer cells and induce the apoptosis of cancer cells (124-126).

The proliferation and metastasis of cancer cells accelerate when immune functions are disturbed. It has been found that cancer patients have lower NK cell activity than healthy controls and persons with lower NK cell activity are subject to higher rates of cancer incidence, metastasis and aggravation of cancer (127-131). The macrophages infiltrating solid tumor have less phagocytic activity (132). On the other hand, when cancer patients ingest foods capable of improving immune functions, the prognosis becomes much better (133-137). Based on the reports of clinical trials with cancer patients, phagocytic activity, NK cell number, T cell number, DTH and IFN- $\gamma$ production are all useful immune parameters for assessing the effect of foods on prognosis after surgical operation for cancer (Table 1). Moreover, it has been reported that NK cell activity deteriorates in AIDS patients (138), and branched chain amino acids, probiotics and vitamin A improves virus-triggered diseases (139-141).

Newborns exhibit immature immune functions and are vulnerable to pathogenic infection. Supplementation of vitamins in malnourished children and ingestion of probiotics in newborns enhance immune functions and prevent viral infection $(118,142)$.

\section{Mechanisms by which Foods Influence Immune Functions}

Food-derived substances incorporated into the body via various routes modulate immune functions. Taking into consideration that malnutrition or calorie restriction cause reduced activity in immune functions, nutritional condition is indispensable for the development of the immune system (143). Moreover, food-derived substances exhibit a special role in influencing immune functions.

The way that food-derived substances modulate immune functions is either indirect or direct. Comparative analyses of conventional and germ-free animals revealed that indigenous intestinal microflora play a pivotal role in the development of host immune systems. Ingestion of probiotics stabilizes the intestinal microflora, and normalization of the intestinal microflora by probiotics could lead to modulation of the host immune system (144). In addition, probiotics such as lactic acid bacteria are recognized by specific receptors on the surface of phagocytic cells. Additionally, vitamins, minerals or fatty acids affect cellular functions by preserving the cell membrane or regulating gene expression after being incorporated into lymphocytes (Fig. 3). One group of foods represented by lactic acid bacteria stimulates innate immunity (phagocytic activity, NK cell activity), while other foods, including vitamins and minerals, activate acquired immunity ( $\mathrm{T}$ cell response, antibody production). However, as innate immunity and acquired immunity are closely linked, both groups of foods may regulate both immune systems. It has been reported that various nutrients found in foods exhibit anti-infectious functions (145). We would like to briefly

Lactic acid bacteria

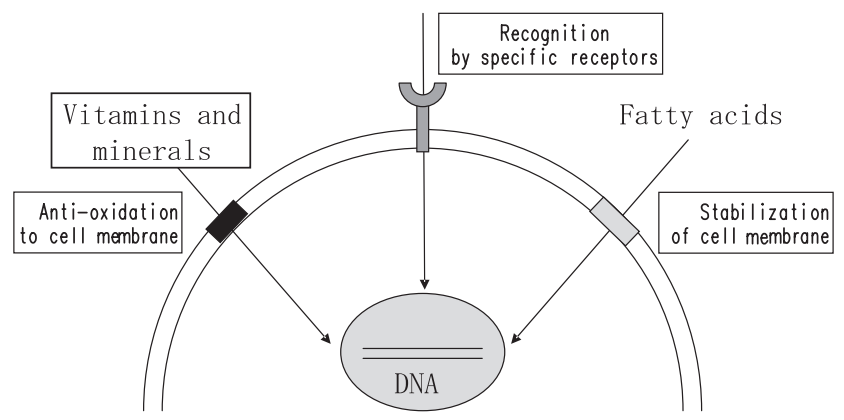

Figure 3. Mechanisms by which food-derived substances modulate the immune functions of cells. Components of probiotics are recognized by cell surface receptors such as the mannose receptor and Toll-like receptors (TLRs). It has been clarified that agonists of TLRs transmit signals to DNA by activating intracellular adaptor molecules such as MyD88. In contrast, vitamins and minerals prevent the oxidation of cell membranes and affect gene expression. Furthermore, fatty acids modulate immune functions by stabilizing the cell membrane and regulate the transcription of genes. 
describe the pathways by which food-derived substances exert their immune-modulating abilities.

Probiotics ingested may be partially digested in the gut and incorporated into $\mathrm{M}$ cells present in FAE, and then captured by dendritic cells or macrophages in the interfollicular area of PPs. These professional phagocytic cells hold various receptors on their surface capable of binding common structures of microbes, the pathogen-associated molecular patterns (PAMPs). Among the receptors for PAMPs, molecular structure and functions of TLRs (Toll-like receptors) have been recently unveiled. Ten TLR families (TLR1-TLR10) have been identified and ligands recognized by some TLRs have been determined. TLR2 recognizes peptidoglycans and lipopeptides as TLR4 does lipoteichoic acids and lipopolysaccharides. Moreover, the $\mathrm{CpG}$ oligonucleotides universally detected in bacterial DNA are recognized by TLR9. The signaling response to stimuli recognized by TLRs is mainly mediated by an intracellular adaptor molecule, MyD88 (myeloid differentiation factor 88). Thereafter, the nuclear transport of NF-кB (nuclear factor-кB) is stimulated and de novo synthesis of cytokines is induced (146). It has been proposed that stimuli through TLR2 activate both JNK (c-Jun N-terminal kinase) and ERK (extracellular signal regulated kinase) and induce production of IL-10, while stimuli through TLR4 activate JNK and induce production of IL-12 (147).

Immune-modulating effects of amino acids such as glutamine and arginine have been evaluated. Ingestion of glutamine improved nitrogen retention and lowered incidence of bacteremia in patients with trauma, and enteral supplementation of glutamine-enriched diet enhanced the recovery of immune functions and reduced the length of hospital stay after surgical operation in cancer patients $(148,149)$. Glutamine is a nutrient for immune cells and acts as precursor for glutathione, which circumvents oxidant stress and improves cell-mediated immunity. Arginine is a substrate for synthesis of nitric oxide and improves helper T-cell numbers. Peri-operative feeding of arginine and n-3 polyunsaturated fatty acids (PUFAs) restored DTH and decreased infection rates in colorectal cancer patients (150).

Nucleotides are rich in foods containing nucleic acid/ nucleoprotein and supplementation of nucleotides is important for growth of infants. Addition of nucleotides increased the proportion of TCR $\gamma \delta$-bearing IELs through stimulating IL-7 production by IECs in mice (151), and ingestion of formula supplemented with nucleotides augmented NK cell activity and IL-2 production in human infants (152). It remains to be elucidated whether immune cells may utilize ingested nucleotides as substrates for synthesis of nucleic acids.

Vitamins and minerals exhibit important immune-modulating functions by entering cells and regulating gene expression. Vitamin A affects the differentiation of epithelial cells and inhibits IFN- $\gamma$ production by $\mathrm{T}$ cells at the transcriptional level, which results in stimulation of antibody-mediated immune responses (153). Vitamin C prevents the production of reactive oxygen intermediates and reduces DNA damage in immune cells. Moreover, vitamin C inhibits the transcription of
Table 2. Major food-derived substances that modulate immune functions

\begin{tabular}{|c|c|}
\hline Nutrients/nutricines & Immune-modulating functions \\
\hline Nutrients/calorie & $\begin{array}{l}\text { Indispensable for normal development of immune } \\
\text { system }\end{array}$ \\
\hline \multicolumn{2}{|l|}{ Amino acids } \\
\hline Glutamine & $\begin{array}{l}\text { Trophic for immune cells, circumvention of oxidant } \\
\text { stress }\end{array}$ \\
\hline Arginine & $\begin{array}{l}\text { Substrate for synthesis of nitric oxide, enhancement } \\
\text { of Th cells }\end{array}$ \\
\hline \multicolumn{2}{|l|}{ Fatty acids } \\
\hline n-3 PUFAs & Anti-inflammatory \\
\hline \multicolumn{2}{|l|}{ Vitamins } \\
\hline Vitamin A & Regulation of Th1/Th2 balance \\
\hline Vitamin $\mathrm{C}$ & Circumvention of oxidant stress \\
\hline Vitamin E & Circumvention of oxidant stress, anti-inflammatory \\
\hline \multicolumn{2}{|l|}{ Minerals } \\
\hline Selenium & Stimulation of cell-mediated immune response \\
\hline Zinc & Stimulation of cell-mediated immune response \\
\hline Nucleotides & Stimulation of cell-mediated immune response \\
\hline \multicolumn{2}{|l|}{ Probiotics } \\
\hline $\begin{array}{l}\text { Peptidoglycan, } \\
\text { lipoteichoic acids }\end{array}$ & Stimulation of IL-12/IL-10 production \\
\hline CpG oligonucleotides & Anti-inflammatory \\
\hline
\end{tabular}

NF- $\kappa \mathrm{B}$, and down-regulates the production of pro-inflammatory cytokines (154). Vitamin $\mathrm{E}$ is also an anti-oxidant and exerts an anti-inflammatory effect. Vitamin E stabilizes the membrane of immune cells and enhances the binding of antigen-presenting cells and $\mathrm{T}$ cells (155).

Minerals prevent the oxidation of lipids in the cell membrane, which can reduce oxidative stress affecting immune cells. For instance, selenium is indispensable to the function of reducing enzymes such as glutathione peroxidase and thioredoxin reductase, and is needed to stimulate cell-mediated immune functions (156). Furthermore, zinc may be required for the translocation and binding of NF- $\kappa \mathrm{B}$ to DNA (157).

Long-chain PUFAs in foods can modulate immune functions. Dietary n-3 PUFAs alter the lipid composition of the cell membrane and regulate the function of immune cells. Antigenpresenting cells from mice and humans fed n-3 PUFAs exhibited the capacity to suppress excessive activation of $\mathrm{T}$ cells $(158,159)$. As a result, $\mathrm{n}-3$ PUFAs can act as antiinflammatory agents.

Major food-derived substances and their immune-modulating functions are summarized in Table 2.

\section{CONCLUDING REMARKS}

We have reviewed and systematized studies reporting the effects of food-derived materials on immune functions in intervention studies or randomized controlled trials in order to clarify whether the immune-modulating activities of foods have been evaluated in a scientific manner. This search has revealed the following points: (i) many foods or food-derived materials improve or enhance immune functions in a wide range of human subjects; and (ii) foods with immune-modulating activities affect either innate or acquired immunity. Phagocytic activity 
and NK cell activity are representative parameters of innate immunity, and phagocytes and NK cells rapidly kill pathogenic bacteria, viruses and cancer cells in an antigen-independent manner. In contrast, DTH, antigen-specific antibody production and the proliferative response of $\mathrm{T}$ cells are major parameters reflecting acquired immunity, which is responsible for the antigen-specific exclusion of pathogenic bacteria, viruses and cancer cells. Many kinds of foods can improve parameters exhibiting either innate or acquired immunity.

Ingestion of foods does not always change many immune parameters. Therefore, it is useful to define immune parameters affected by foods. Vitamins, minerals, amino acids, proteins, carbohydrates or lipids, for example, enhance parameters of acquired immunity. In contrast, probiotics, including lactic acid bacteria, mainly augment parameters of innate immunity. These findings support that food-derived materials act on different immune cells or distinct molecules of the cells and improve at least one parameter of either innate or acquired immunity. In other words, these results mean that one can evaluate the immune-modulating abilities of foods by analyzing parameters of either innate or acquired immunity.

The components in foods that improve immune functions and the mechanisms by which foods exert immune-modulating effects are still far from fully understood. To confirm the scientific basis of the immune-modulating activities of foods, there is a need to keep on systematizing newly obtained scientific data on foods.

\section{Acknowledgements}

Grateful thanks are extended to Dr Mitsuo Ikeda, Mr Tomoyasu Toyoda, Mr Michishiro Ito, Dr Kunio Ezawa, Dr Shigetaka Ishii, Dr Kazuo Yoshioka, Dr Hirofumi Koda, Dr Lekh Raj Juneja, Dr Yoshihiro Yamamoto, Dr Teruo Nakakuki, Dr Taizo Nagura, Mr Chiaki Sanbongi, Dr Takeshi Takahashi, Mr Hirotoshi Hayasawa and Dr Hiroshi Kawakami, all of whom are members of the Association of Food Immunology, for critical reading and helpful discussion of the manuscript.

\section{References}

1. Weiner ML. Intestinal transport of some macromolecules in food. Food Chem Toxic 1988;26:867-80.

2. Owen RL. Sequential uptake of horseradish peroxidase by lymphoid follicle epithelium of Peyer's patches in the normal unobstructed mouse intestine: an ultrastructural study. Gastroenterology 1977;72:440-51.

3. Keljo DJ, Hamilton JR. Quantitative determination of macromolecular transport rate across intestinal Peyer's patches. Am J Physiol 1983;244:G637-44.

4. Roberton DM, Paganelli R, Dinwiddie R, Levinsky RJ. Milk antigen absorption in the preterm and term neonate. Arch Dis Child 1982;57:369-72.

5. Jackson PG, Lessof MH, Baker RW, Ferrett J, MacDonald DM. Intestinal permeability in patients with eczema and food allergy. Lancet 1981;8233:1285-6.

6. Nanno M, Kanamori Y, Saito H, Kawaguchi-Miyashita M, Shimada S, Ishikawa H. Intestinal intraepithelial T lymphocytes. Our T cell horizons are expanding. Immunol Res 1998;18:41-53.

7. Smyth MJ, Crowe NY, Hayakawa Y, Takeda K, Yagita H, Godfrey DI. NKT cells-conductors of tumor immunity? Curr Opin Immunol 2002; $14: 165-71$.
8. Duchmann R, Kaiser I, Harmann E, Mayet W, Ewe K, Meyer zum Buscherfelde $\mathrm{KH}$. Tolerance exists towards resident intestinal flora but is broken in active inflammatory bowel disease (IBD). Clin Exp Immunol 1995; 102:448-55.

9. Hashimoto K, Kawagishi H, Nakayama T, Shimizu M. Effect of capsianoside, a diterpene glycoside, on tight-junctional permeability. Biochim Biophys Acta 1997;1323:281-90.

10. Rescigno M, Urbano M, Valzasina B, et al. Dendritic cells express tight junction proteins and penetrate gut epithelial monolayers to sample bacteria. Nat Immunol 2001;2:361-7.

11. Fagnoni FF, Vescovini R, Passeri G, et al. Shortage of circulating naive $\mathrm{CD}^{+} \mathrm{T}$ cells provides new insights on immunodeficiency in aging. Blood 2000;95:2860-8.

12. Fagnoni FF, Vescovini R, Mazzola M, et al. Expansion of cytotoxic $\mathrm{CD} 8^{+} \mathrm{CD} 28^{-} \mathrm{T}$ cells in healthy ageing people, including centenarians. Immunology 1996;88:501-7.

13. Stulnig T, Maczek C, Bock G, Majdic O, Wick G. Reference intervals for human peripheral blood lymphocyte subpopulations from 'healthy' young and aged subjects. Int Arch Allergy Immunol 1995;108:205-10.

14. Sansoni P, Cossarizza A, Brianti V, et al. Lymphocyte subsets and natural killer cell activity in healthy old people and centenarians. Blood 1993;82:2767-73.

15. Mariani E, Ravaglia G, Forti P, et al. Vitamin D, thyroid hormones and muscle mass influence natural killer (NK) innate immunity in healthy nonagenarians and centenarians. Clin Exp Immunol 1999;116:19-27.

16. Ravaglia G, Forti P, Maioli F, et al. Effect of micronutrient status on natural killer cell immune function in healthy free-living subjects aged $>90$ y. Am J Clin Nutr 2000;71:590-8.

17. Vedhara K, Cox NK, Wilcock GK, et al. Chronic stress in elderly carers of dementia patients and antibody response to influenza vaccination. Lancet 1999;353:627-31.

18. Kiecolt-Glaser JK, Dura JR, Speicher CE, Trask OJ, Glaser R. Spousal caregivers of dementia victims: longitudinal changes in immunity and health. Psychosom Med 1991;53:345-62.

19. Glaser R, Kiecolt-Glaser JK. Chronic stress modulates the virus-specific immune response to latent herpes simplex virus type 1. Ann Behav Med 1997; 19:78-82.

20. Esterling BA, Kiecolt-Glaser JK, Bodnar JC, Glaser R. Chronic stress, social support, and persistent alterations in the natural killer cell response to cytokines in older adults. Health Psychol 1994;13:291-8.

21. Evans DL, Leserman J, Pedersen CA, et al. Immune correlates of stress and depression. Psychopharmacol Bull 1989;25:319-24.

22. Kiecolt-Glaser JK, Glaser R, Strain EC, et al. Modulation of cellular immunity in medical students. J Behav Med 1986;9:5-21.

23. Nieman DC. Immune response to heavy exertion. J Appl Physiol 1997;82:1385-94.

24. Irwin M, Patterson T, Smith TL, et al. Reduction of immune function in life stress and depression. Biol Psychiatry 1990;27:22-30.

25. Brussow H, Sidoti J, Dirren H, Freire WB. Effect of malnutrition in Ecuadorian children on titers of serum antibodies to various microbial antigens. Clin Diag Lab Immunol 1995;2:62-8.

26. Ledesma F, Echevarria S, Casafont F, Lozano JL, Pons-Romero F. Natural killer cell activity in alcoholic cirrhosis: influence of nutrition. Eur J Clin Nutr 1990;44:733-40.

27. Vasquez-Garibay E, Campollo-Rivas O, Romero-Velarde E, et al. Effect of renutrition on natural and cell-mediated immune response in infants with severe malnutrition. J Pediatr Gastroenterol Nutr 2002;34:296-301.

28. Lotfy OA, Saleh WA, el-Barbari M. A study of some changes of cellmediated immunity in protein energy malnutrition. J Egypt Soc Parasitol 1998;28:413-28.

29. Birmaher B, Rabin BS, Garcia MR, et al. Cellular immunity in depressed, conduct disorder, and normal adolescents: role of adverse life events. J Am Acad Child Adolesc Psychiatry 1994;33:671-8.

30. de la Fuente M, Ferrandez MD, Burgos MS, Soler A, Prieto A, Miquel J. Immune function in aged women is improved by ingestion of vitamins $\mathrm{C}$ and E. Can J Physiol Pharmacol 1998;76:373-80.

31. Patarca R. Cytokines and chronic fatigue syndrome. Ann NY Acad Sci 2001;933:185-200.

32. Marrie TJ, Johnson S, Durant H. Cell-mediated immunity of healthy adult Nova Scotians in various age groups compared with nursing home and hospitalized senior citizens. J Allergy Clin Immunol 1988;81:836-43.

33. Wayne SJ, Rhyne RL, Garry PJ, Goodwin JS. Cell-mediated immunity as a predictor of morbidity and mortality in subjects over 60. J Gerontol 1990;45:M45-8. 
34. Levy SM, Herberman RB, Lee J, et al. Persistently low natural killer cell activity, age, and environmental stress as predictors of infectious morbidity. Nat Immun Cell Growth Regul 1991;10:289-307.

35. Castle SC. Clinical relevance of age-related immune dysfunction. Clin Infect Dis 2000;3:578-85.

36. Hassan IS, Bannister BA, Akbar A, Weir W, Bofill M. A study of the immunology of the chronic fatigue syndrome: correlation of immunologic parameters to health dysfunction. Clin Immunol Immunopathol 1998;87:60-7.

37. Wu D, Meydani M, Leka LS, et al. Effect of dietary supplementation with black currant seed oil on the immune response of healthy elderly subjects. Am J Clin Nutr 1999;70:536-43.

38. Meydani SN, Barklund MP, Liu S, et al. Vitamin E supplementation enhances cell-mediated immunity in healthy elderly subjects. Am J Clin Nutr 1990;52:557-63.

39. Sempertegui F, Estrella B, Correa E, et al. Effects of short-term zinc supplementation on cellular immunity, respiratory symptoms, and growth of malnourished Equadorian children. Eur J Clin Nutr 1996;50:42-6.

40. Han SN, Leka LS, Lichtenstein AH, Ausman LM, Schaefer EJ, Meydani SN. Effect of hydrogenated and saturated, relative to polyunsaturated, fat on immune and inflammatory responses of adults with moderate hypercholesterolemia. J Lipid Res 2002;43:445-52.

41. Girodon F, Galan P, Monget AL, et al. Impact of trace elements and vitamin supplementation on immunity and infections in institutionalized elderly patients: a randomized controlled trial. MIN. VIT. AOX. geriatric network. Arch Intern Med 1999;159:748-54.

42. Provinciali M, Montenovo A, Di Stefano G, et al. Effect of zinc or zinc plus arginine supplementation on antibody titer and lymphocyte subsets after influenza vaccination in elderly subjects: a randomized controlled trial. Age Ageing 1998;27:715-22.

43. Chandra RK. Effect of vitamin and trace-element supplementation on immune responses and infection in elderly subjects. Lancet 1992;340:1124-7.

44. Bahl R, Kumar R, Bhandari N, Kant S, Srivastava R, Bhan MK. Vitamin A administered with measles vaccine to nine-month-old infants does not reduce vaccine immunogenicity. J Nutr 1999;129:1569-73.

45. Wouters-Wesseling W, Rozendaal M, Snijder M, et al. Effect of a complete nutritional supplement on antibody response to influenza vaccine in elderly people. J Gerontol A Biol Sci Med Sci 2002; 57:M563-6.

46. Baumann W, Hanisch M, Emmrich P, Arnold W. Management of hepatic coma due to fulminant viral hepatitis B using anti-HB plasma. Monatsschr Kinderheilkd 1978;126:335-7 (in German).

47. Kramer TR, Udomkesmalee E, Dhanamitta S, et al. Lymphocyte responsiveness of children supplemented with vitamin A and zinc. Am J Clin Nutr 1993;58:566-70.

48. Fortes C, Forastiere F, Agabiti N, et al. The effect of zinc and vitamin A supplementation on immune response in an older population. $J \mathrm{Am}$ Geriatr Soc 1998;46:19-26.

49. Murosaki S, Ikematsu H, Yamamoto Y, Yukami S, Nomoto K. Effects of intake of nigerooligosaccharides-supplemented syrup on the immune function and quality of life in the healthy elderly. Jpn Pharmacol Ther 2001;29:815-26.

50. Murosaki S, Ikematsu H, Hirose Y, Yamamoto Y, Yukami S, Nomoto K. Effects of intake of nigerooligosaccharides-supplemented syrup on the immune function and quality of life in healthy young adult subjects. Jpn Pharmacol Ther 2002;30:81-90.

51. Pike J, Chandra RK. Effect of vitamin and trace element supplementation on immune indices in healthy elderly. Int $J$ Vitam Nutr Res 1995;65:117-21.

52. Heuser G, Vojdani A. Enhancement of natural killer cell activity and T and B cell function by buffered vitamin $\mathrm{C}$ in patients exposed to toxic chemicals: the role of protein kinase-C. Immunopharmacol Immunotoxicol 1997;19:291-312.

53. Sheih YH, Chiang BL, Wang LH, Liao CK, Gill HS. Systemic immunityenhancing effects in healthy subjects following dietary consumption of the lactic acid bacterium Lactobacillus rhamnosus HN001. J Am Coll Nutr 2001;20 (2 Suppl):149-56.

54. Nagao F, Nakayama M, Muto T, Okumura K. Effects of a fermented milk drink containing Lactobacillus casei strain Shirota on the immune system in healthy human subjects. Biosci Biotechnol Biochem 2000;64:2706-8.

55. Gill HS, Rutherfurd KJ, Cross ML, Gopal PK. Enhancement of immunity in the elderly by dietary supplementation with the probiotic Bifidobacterium lactis HN019. Am J Clin Nutr 2001;74:833-9.
56. Chiang BL, Sheih YH, Wang LH, Liao CK, Gill HS. Enhancing immunity by dietary consumption of a probiotic lactic acid bacterium (Bifidobacterium lactis HN019): optimization and definition of cellular immune responses. Eur J Clin Nutr 2000;54:849-55.

57. Santos MS, Gaziano JM, Leka LS, Beharka AA, Hennekens CH, Meydani SN. Beta-carotene-induced enhancement of natural killer cell activity in elderly men: an investigation of the role of cytokines. Am J Clin Nutr 1998;68:164-70.

58. Kiremidjian-Schumacher L, Roy M, Wishe HI, Cohen MW, Stotzky G. Supplementation with selenium and human immune cell functions. II. Effect on cytotoxic lymphocytes and natural killer cells. Biol Trace Elem Res 1994;41:115-27. [Erratum in: Biol Trace Elem Res 1994;46:183.]

59. Schiffrin EJ, Brassart D, Servin AL, Rochat F, Donnet-Hughes A. Immune modulation of blood leukocytes in humans by lactic acid bacteria: criteria for strain selection. Am J Clin Nutr 1997;66:515S-20S.

60. Schiffrin EJ, Rochat F, Link-Amster H, Aeschlimann JM, Donnet-Hughes A. Immunomodulation of human blood cells following the ingestion of lactic acid bacteria. J Dairy Sci 1995;78:491-7.

61. Arunachalam K, Gill HS, Chandra RK. Enhancement of natural immune function by dietary consumption of Bifidobacterium lactis (HN019). Eur J Clin Nutr 2000;54:263-7.

62. Sempertegui F, Estrella B, Correa E, et al. Effects of short-term zinc supplementation on cellular immunity, respiratory symptoms, and growth of malnourished Equadorian children. Eur J Clin Nutr 1996;50:42-6.

63. Field CJ. Use of $\mathrm{T}$ cell function to determine the effect of physiologically active food components. Am J Clin Nutr 2000;71:1720S-7S.

64. Junghans V, Gutgesell C, Jung T, Neumann C. Epidermal cytokines IL-1beta, TNF-alpha, and IL-12 in patients with atopic dermatitis: response to application of house dust mite antigens. J Invest Dermatol 1998;111:1184-8.

65. Turchet P, Laurenzato M, Auboiron S, Antonie JM. Effect of fermented milk containing the probiotic Lactobacillus casei DN-114 001 on winter infections in free-living elderly subjects: A randomized, controlled pilot study. J Nutr Health Aging 2003;7:75-7.

66. Sakurai T, Inagaki N, Nagai $\mathrm{H}$. The effect of anti-tumor necrosis factor (TNF)-alpha monoclonal antibody on allergic cutaneous late phase reaction in mice. Life Sci 1994;54:PL291-5.

67. Isolauri E, Arvola T, Sutas Y, Moilanen E, Salminen S. Probiotics in the management of atopic eczema. Clin Exp Allergy 2000;30:1604-10.

68. Ito H, Nakamura Y, Takagi S, Sakai K. Effects of azelastine on the level of serum interleukin- 4 and soluble CD23 antigen in the treatment of nasal allergy. Arzneimittelforschung 1998;48:1143-7.

69. Colver GB, Symons JA, Duff GW. Soluble interleukin 2 receptor in atopic eczema. Br Med J 1989;298:1426-8.

70. Schleimer RP, Sterbinsky SA, Kaiser J, et al. IL-4 induces adherence of human eosinophils and basophils but not neutrophils to endothelium. Association with expression of VCAM-1. J Immunol 1992;148:1086-92.

71. Koller DY, Halmerbauer G, Frischer T, Roithner B. Assessment of eosinophil granule proteins in various body fluids: is there a relation to clinical variables in childhood asthma? Clin Exp Allergy 1999;29:786-93.

72. Bousquet J, Chanez P, Lacoste JY, et al. Eosinophilic inflammation in asthma. N Engl J Med 1990;323:1033-9.

73. Leonardi A, Battista MC, Gismondi M, Fregona IA, Secchi AG. Antigen sensitivity evaluated by tear-specific and serum-specific IgE, skin tests, and conjunctival and nasal provocation tests in patients with ocular allergic disease. Eye 1993;7:461-4.

74. [No authors listed] Severity scoring of atopic dermatitis: the SCORAD index. Consensus Report of the European Task Force on Atopic Dermatitis. Dermatology 1993;186:23-31.

75. Thien FC, Atkinson BA, Khan A, Mencia-Huerta JM, Lee TH. Effect of dietary fish oil supplementation on the antigen-induced late-phase response in the skin. J Allergy Clin Immunol 1992;89:829-35.

76. La Rosa M, Ranno C, Andre C, Carat F, Tosca MA, Canonica GW. Doubleblind placebo-controlled evaluation of sublingual-swallow immunotherapy with standardized Parietaria judaica extract in children with allergic rhinoconjunctivitis. J Allergy Clin Immunol 1999;104:425-32.

77. Purello-D'Ambrosio F, Gangemi S, et al. Sublingual immunotherapy: a double-blind, placebo-controlled trial with Parietaria judaica extract standardized in mass units in patients with rhinoconjunctivitis, asthma, or both. Allergy 1999;54:968-73.

78. Latchman Y, Banerjee P, Poulter LW, Rustin M, Brostoff J. Association of immunological changes with clinical efficacy in atopic eczema patients treated with traditional Chinese herbal therapy (Zemaphyte). Int Arch Allergy Immunol 1996;109:243-9. 
79. Majamaa H, Isolauri E. Probiotics: a novel approach in the management of food allergy. J Allergy Clin Immunol 1997;99:179-85.

80. Pessi T, Sutas Y, Hurme M, Isolauri E. Interleukin-10 generation in atopic children following oral Lactobacillus rhamnosus GG. Clin Exp Allergy 2000;30:1804-8.

81. Wheeler JG, Shema SJ, Bogle ML, et al. Immune and clinical impact of Lactobacillus acidophilus on asthma. Ann Allergy Asthma Immunol 1997;79:229-33.

82. Kalliomaki M, Salminen S, Arvilommi H, Kero P, Koskinen P, Isolauri E. Probiotics in primary prevention of atopic disease: a randomised placebo-controlled trial. Lancet 2001;357:1076-9.

83. Kalliomaki M, Salminen S, Poussa T, Arvilommi H, Isolauri E. Probiotics and prevention of atopic disease: 4-year follow-up of a randomized placebo-controlled trial. Lancet 2003;361:1869-71.

84. Rautava S, Kalliomaki M, Isolauri E. Probiotics during pregnancy and breast-feeding might confer immunomodulatory protection against atopic disease in the infant. J Allergy Clin Immunol 2002;109:119-21.

85. Kirjavainen PV, Arvola T, Salminen SJ, Isolauri E. Aberrant composition of gut microbiota of allergic infants: a target of bifidobacterial therapy at weaning? Gut 2002;51:51-5.

86. Rosenfeldt V, Benfeldt E, Nielsen SD, et al. Effect of probiotic Lactobacillus strains in children with atopic dermatitis. J Allergy Clin Immunol 2003;111:389-95.

87. Hattori K, Yamamoto A, Sasai M, et al. Effects of administration of bifidobacteria on fecal microflora and clinical symptoms in infants with atopic dermatitis. Jpn J Allergol 2003;52:20-30 (in Japanese).

88. Shida K, Makino K, Morishita A, et al. Lactobacillus casei inhibits antigeninduced IgE secretion through regulation of cytokine production in murine splenocyte cultures. Int Arch Allergy Immunol 1998; 115:278-87.

89. Ishida Y, Bandou I, Kanzato H, Yamamoto N. Decrease in ovalbumin specific IgE of mice serum after oral uptake of lactic acid bacteria. Biosci Biotechnol Biochem 2003;67:951-7.

90. Portales P, Aries MF, Licu D, et al. Immunomodulation induced by Avene spring water on Th1- and Th2-dependent cytokine production in healthy subjects and atopic dermatitis patients. Skin Pharmacol. Appl Skin Physiol 2001;14:234-42.

91. Benlounes N, Dupont C, Candalh C, Blaton MA, Bloom M, Heyman M. Effect of terfenadine on TNF alpha release from peripheral blood mononuclear cells during cow's milk allergy. Clin Exp Allergy 1997;27:942-8.

92. Kim K.M, Nanbu M, Iwai Y, et al. Soluble low affinity Fc receptors for $\operatorname{IgE}$ in the serum of allergic and nonallergic children. Pediatr Res 1989;26:49-53.

93. Kagi MK, Joller-Jemelka H, Wuthrich B. Correlation of eosinophils, eosinophil cationic protein and soluble interleukin-2 receptor with the clinical activity of atopic dermatitis. Dermatology 1992;185:88-92.

94. Sutas Y, Hurme M, Isolauri E. Down-regulation of anti-CD3 antibodyinduced IL-4 production by bovine caseins hydrolysed with Lactobacillus GG-derived enzymes. Scand J Immunol 1996;43:687-9.

95. Nishioka K, Saito C, Nagano T, Okano M, Masuda Y, Kuriyama T. Eosinophil cationic protein in the nasal secretions of patients with mite allergic rhinitis. Larynagoscope 1993;103:189-92.

96. Kaburagi Y, Shimada Y, Nagaoka T, Hasegawa M, Takehara K, Sato S. Enhanced production of CC-chemokines (RANTES, MCP-1, MIP1alpha, MIP-1beta, and eotaxin) in patients with atopic dermatitis. Arch Dermatol Res 2001;293:350-5.

97. Wuthrich B, Joller-Jemelka H, Kagi MK. Levels of soluble ICAM-1 in atopic dermatitis. A new marker for monitoring the clinical activity? Allergy 1995;50:88-9.

98. Hansen G, McIntire JJ, Yeung VP, et al. $\mathrm{CD}^{+}{ }^{+} \mathrm{T}$ helper cells engineered to produce latent TGF- $\beta 1$ reverse allergen-induced airway hyperreactivity and inflammation. J Clin Invest 2000;105:61-70.

99. Wilson N, Pedersen S. Inflammatory markers in clinical practice. Am J Respir Crit Care Med 2000;162:S48-51.

100. Nagura T, Hachimura S, Hashiguchi M, et al. Suppressive effect of dietary raffinose on T-helper 2 cell-mediated immunity. $\mathrm{Br} J$ Nutr 2002;88:421-6.

101. Takano H, Osakabe N, Sanbongi C, et al. Extract of Perilla frutescens enriched for rosmarinic acid, a polyphenolic phytochemical, inhibits seasonal allergic rhinoconjunctivitis in humans. Exp Biol Med (Maywood) 2004;229:247-54.

102. Nagafuchi S, Hachimura S, Totsuka M, et al. Dietary nucleotides can up-regulate antigen-specific Th1 immune responses and suppress antigen-specific IgE responses in mice. Int Arch Allergy Immunol 2000;122:33-41.
103. Hunter CA. How are NK cell responses regulated during infection? Exp Parasitol 1996;84:444-8.

104. Tay CH, Szomolanyi-Tsuda E, Welsh RM. Control of infections by NK cells. Curr Top Microbiol Immunol 1998;230:193-220.

105. Fleming SD, Campbell PA, Some macrophages kill Listeria monocytogenes while others do not. Immunol Rev 1997;158:69-77.

106. Vazquez-Torres A, Fang FC, Oxygen-dependent anti-Salmonella activity of macrophages. Trends Microbiol 2001;9:29-33.

107. Daele J, Zicot AF. Humoral immunodeficiency in recurrent upper respiratory tract infections. Some basic, clinical and therapeutic features. Acta Otorhinolaryngol Belg 2000;54:373-90.

108. Bloom PD, Boedeker EC. Mucosal immune responses to intestinal bacterial pathogens. Semin Gastrointest Dis 1996;7:151-66.

109. Uehling DT, Johnson DB, Hopkins WJ. The urinary tract response to entry of pathogens. World J Urol 1999;17:351-8.

110. Marteau P, Vaerman JP, Dehennin JP, et al. Effects of intrajejunal perfusion and chronic ingestion of Lactobacillus johnsonii strain La1 on serum concentrations and jejunal secretions of immunoglobulins and serum proteins in healthy humans. Gastroenterol Clin Biol 1997;21:293-8.

111. Biron CA, Byron KS, Sullivan JL. Severe herpesvirus infections in an adolescent without natural killer cells. $N$ Engl J Med 1989;320:1731-5.

112. Bukowski JF, Warner JF, Dennert G, Welsh RM. Adoptive transfer studies demonstrating the antiviral effect of natural killer cells in vivo. $J$ Exp Med 1985;161:40-52.

113. Marodi L, Kaposzta R, Toth J, Laszlo A. Impaired microbicidal capacity of mononuclear phagocytes from patients with type I Gaucher disease: partial correction by enzyme replacement therapy. Blood 1995;86:4645-9.

114. Storek J, Espino G, Dawson MA, Storer B, Flowers ME, Maloney DG. Low B-cell and monocyte counts on day 80 are associated with high infection rates between days 100 and 365 after allogeneic marrow transplantation. Blood 2000;96:3290-3.

115. Braga M, Vignali A, Gianotti L, Cestari A, Profili M, Carlo VD. Immune and nutritional effects of early enteral nutrition after major abdominal operations. Eur J Surg 1996;162:105-12.

116. Scaglione F, Cattaneo G, Alessandria M, Cogo R. Efficacy and safety of the standardised Ginseng extract G115 for potentiating vaccination against the influenza syndrome and protection against the common cold [corrected]. Drugs Exp Clin. Res 1996;22:65-72.

117. Kaila M, Isolauri E, Soppi E, Virtanen E, Laine S, Arvilommi H. Enhancement of the circulating antibody secreting cell response in human diarrhea by a human Lactobacillus strain. Pediatr Res 1992;32:141-4.

118. Coutsoudis A, Kiepiela P, Coovadia HM, Broughton M. Vitamin A supplementation enhances specific IgG antibody levels and total lymphocyte numbers while improving morbidity in measles. Pediatr Infect Dis J 1992;11:203-9.

119. Trinchieri G. Biology of natural killer cells. Adv Immunol 1989;47:187-376.

120. Hercend T, Schmidt RE. Characteristics and uses of natural killer cells. Immunol Today 1988;9:291-3.

121. Ravetch JV, Lanier LL. Immune inhibitory receptors. Science 2000;290:84-9.

122. Tannenbaum CS, Hamilton TA. Immune-inflammatory mechanisms in IFNgamma-mediated anti-tumor activity. Semin Cancer Biol 2000;10:113-23.

123. Ikeda H, Old LJ, Schreiber RD. The roles of IFN gamma in protection against tumor development and cancer immunoediting. Cytokine Growth Factor Rev 2002;13:95-109.

124. Albina JE, Reichner JS. Role of nitric oxide in mediation of macrophage cytotoxicity and apoptosis. Cancer Metastasis Rev 1998;17:39-53.

125. Zavadova E, Loercher A, Verstovsek S, Verschraegen CF, Micksche M, Freedman RS. The role of macrophages in antitumor defense of patients with ovarian cancer. Hematol Oncol Clin North Am 1999;13:135-44.

126. te Velde AA, Figdor CG. Monocyte mediated cytotoxic activity against melanoma. Melanoma Res 1992;1:303-9.

127. Balch CM, Tilden AB, Dougherty PA, Cloud GA. Depressed levels of granular lymphocytes with natural killer (NK) cell function in 247 cancer patients. Ann Surg 1983;198:192-9.

128. Brenner BG, Friedman G, Margolese RG. The relationship of clinical status and therapeutic modality to natural killer cell activity in human breast cancer. Cancer 1985;56:1543-8.

129. Strayer DR, Carter WA, Mayberry SD, Pequignot E, Brodsky I. Low natural cytotoxicity of peripheral blood mononuclear cells in individuals with high familial incidences of cancer. Cancer Res 1984;44:370-4. 
130. Purtilo DT, Strobach RS, Okano M, Davis JR. Epstein-Barr virusassociated lymphoproliferative disorders. Lab Invest 1992;67:5-23.

131. Imai K, Matsuyama S, Miyake S, Suga K, Nakachi K. Natural cytotoxic activity of peripheral-blood lymphocytes and cancer incidence: An 11year follow-up study of a general population. Lancet 2000;356:1795-9.

132. Hermann M, Niemitz C, Marafioti T, Schriever F. Reduced phagocytosis of apoptotic cells in malignant lymphoma. Int J Cancer 1998;75:675-9.

133. Braga M, Vignali A, Gianotti L, Cestari A, Profili M, Carlo VD. Immune and nutritional effects of early enteral nutrition after major abdominal operations. Eur J Surg 1996;162:105-12.

134. Isenberg J, Stoffel B, Wolters U, et al. Immunostimulation by propionibacteria-effects on immune status and antineoplastic treatment. Anticancer Res 1995;15:2363-8.

135. Kemen M, Senkal M, Homann HH, et al. Early postoperative enteral nutrition with arginine-omega-3 fatty acids and ribonucleic acid-supplemented diet versus placebo in cancer patients: an immunologic evaluation of Impact. Crit Care Med 1995;23:652-9.

136. Song JX, Qing SH, Huang XC, Qi DL. Effect of parenteral nutrition with L-arginine supplementation on postoperative immune function in patients with colorectal cancer. Di Yi Jun Yi Da Хие Хие Bao 2002;22:545-7.

137. Braga M, Gianotti L, Vignali A, Carlo VD. Preoperative oral arginine and n-3 fatty acid supplementation improves the immunometabolic host response and outcome after colorectal resection for cancer. Surgery 2002;132:805-14.

138. Plaeger-Marshall S, Spina CA, et al. Alterations in cytotoxic and phenotypic subsets of natural killer cells in acquired immune deficiency syndrome (AIDS). J Clin Immunol 1987;7:16-23.

139. Takegoshi K, Nanasawa H, Itoh H, Yasuyama T, Ohmoto Y, Sugiyama K. Effects of branched-chain amino acid-enriched nutrient mixture on natural killer cell activity in viral cirrhosis. Arzneimittelforschung 1998;48:701-6.

140. Araki K, Shinozaki T, Irie Y, Miyazawa Y. Trial of oral administration of Bifidobacterium breve for the prevention of rotavirus infections. Kansenshogaku Zasshi 1999;73:305-10 (in Japanese).

141. Coutsoudis A, Kiepiela P, Coovadia HM, Broughton M. Vitamin A supplementation enhances specific IgG antibody levels and total lymphocyte numbers while improving morbidity in measles. Pediatr Infect Dis J 1992;11:203-9.

142. Hatakka K, Savilahti E, Pönkä A, et al. Effect of long term consumption of probiotic milk on infections in children attending day care centers: Double blind, randomized trial. Br Med J 2001;322:1-5.

143. Amati L, Cirimele D, Pugliese V, Covelli V, Resta F, Jirillo E. Nutrition and immunity: laboratory and clinical aspects. Curr Pharm Des 2003;9:1924-31.

144. Fuller R. Probiotics in human medicine. Gut 1991;32:439-42.
145. Field CJ, Johnson IR, Schley PD. Nutrients and their role in host resistance to infection. J Leukocyte Biol 2002;71:16-32.

146. Takeda K, Kaisho T, Akira S. Toll-like receptors. Апnи Rev Immunol 2003;21:335-76.

147. Agrawal S, Agrawal A, Doughty B, et al. Different Toll-like receptor agonists instruct dendritic cells to induce distinct Th responses via differential modulation of extracellular signal-regulated kinase-mitogenactivated protein kinase and c-fos. J Immunol 2003;171:4984-9.

148. Houdjik APJ, Rijnsburger ER, Jansen J, et al. Randomized trial of glutamine-enriched enteral nutrition on infectious morbidity in patients with multiple trauma. Lancet 1998;352:772-6.

149. Morlion BJ, Stehle P, Wachtler P, et al. Total parenteral nutrition with glutamine dipeptide after major surgery. A double blind controlled study. Ann Surg 1998;227:302-8.

150. Gionotti L, Braga M, Fortis C, et al. A prospective randomized clinical trial on perioperative feeding with arginine, omega 3 fatty acid, and RNA-enriched enteral diet. Effect on host response and nutrient status. $J$ Parent Ent Nutr 1999;23:314-20.

151. Nagafuchi S, Totsuka M, Hachimura S, et al. Dietary nucleotides increase the proportion of a TCR $\gamma \delta^{+}$subset of intraepithelial lymphocytes (IEL) and IL-7 production by intestinal epithelial cells (IEC); implications for modification of cellular and molecular cross-talk between IEL and IEC by dietary nucleotides. Biosci Biotechnol Biochem 2000;64:1459-65.

152. Carver JD. Dietary nucleotides: cellular immune, intestinal and hepatic system effects. J Nutr 1994;124:144S-8S.

153. Cantorna MT, Nashold FE, Hayes CE. Vitamin A deficiency results in a priming environment conductive for Th1 cell development. Eur $J$ Immunol 1995;25:1673-9.

154. Schwager J, Schulze J. Modulation of interleukin production by ascorbic acid. Vet Immunol Immunopathol 1998;64:45-57.

155. Moriguchi S, Itoh T. Vitamin E enhances $\mathrm{T}$ cell differentiation through increased epithelial cell function in rat thymus. Nutr Res 1997; 17:873-83.

156. McKenzie RC, Rafferty TS, Beckett GJ. Selenium: an essential element for immune function. Immunol Today 1998;19:342-5.

157. Prasad AS. Effects of zinc deficiency on Th1 and Th2 cytokine shifts. $J$ Infect Dis 2000;182:S62-8.

158. Fujikawa M, Yamashita N, Yamazaki K, Sugiyama E, Suzuki H, Hamazaki T. Eicosapentanoic acid inhibits antigen-presenting cell function of murine splenocytes. Immunology 1992;75:330-5.

159. Hughes DA, Pinder AC. N-3 Polyunsaturated fatty acids inhibit the antigen-presenting function of human monocytes. Am J Clin Nutr 2000;71:357S-60S.

Received May 6, 2004; accepted August 31, 2004 


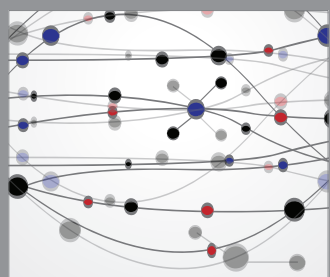

The Scientific World Journal
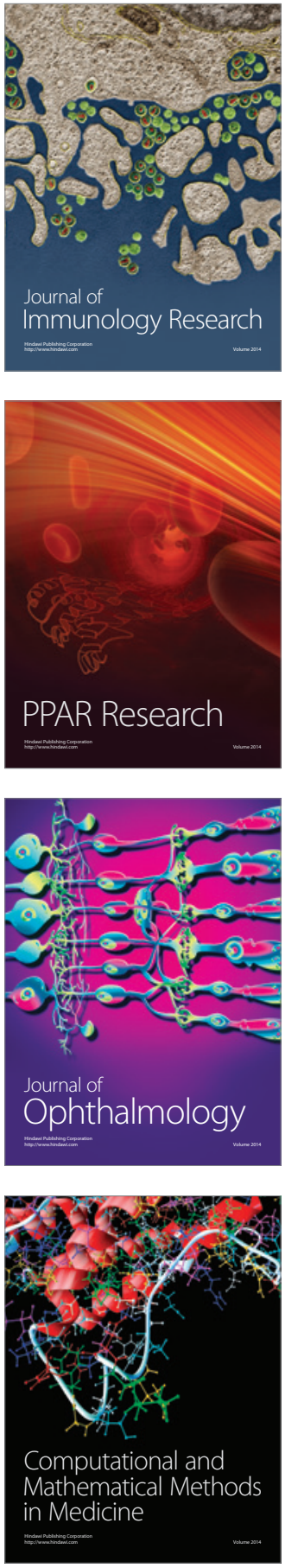

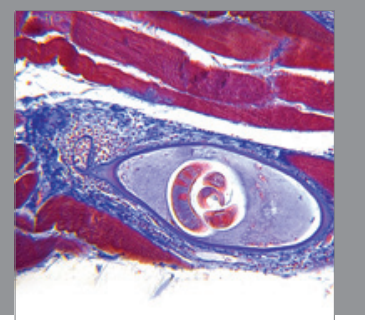

Gastroenterology

Research and Practice
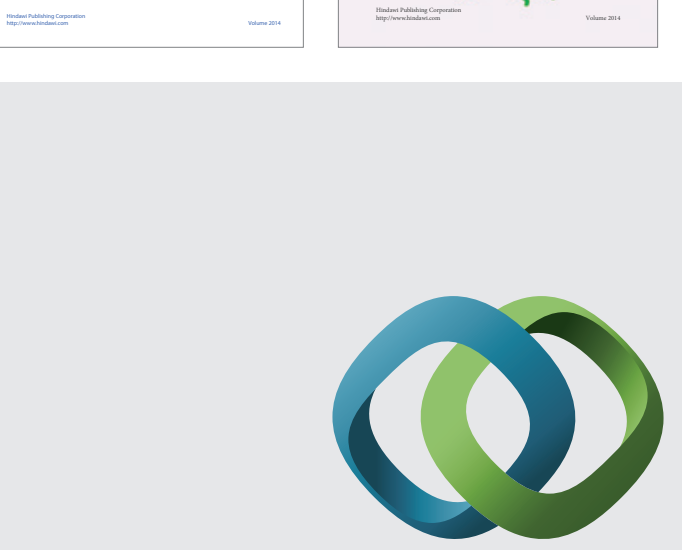

\section{Hindawi}

Submit your manuscripts at

http://www.hindawi.com
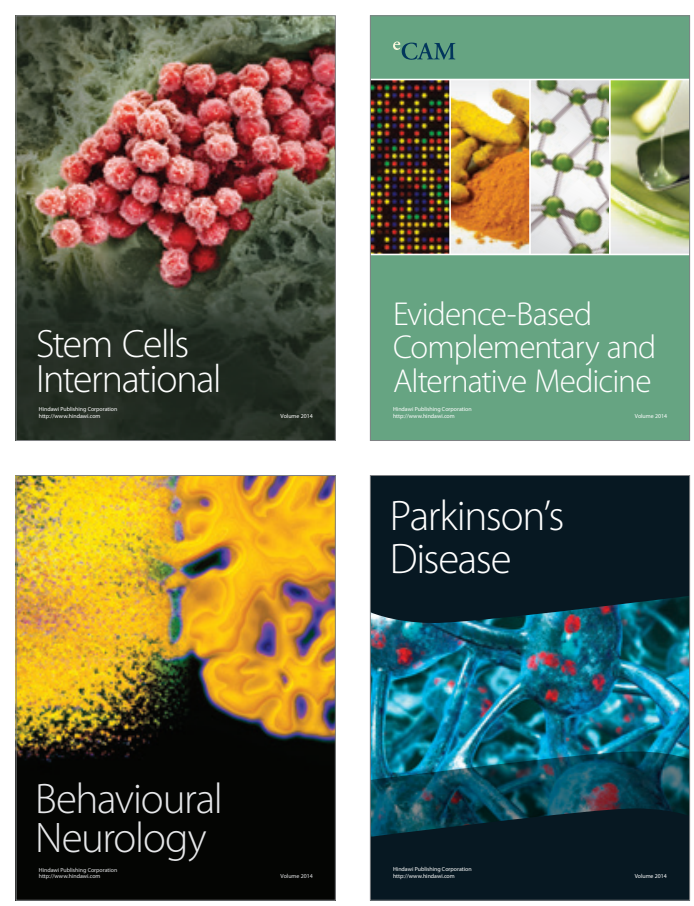

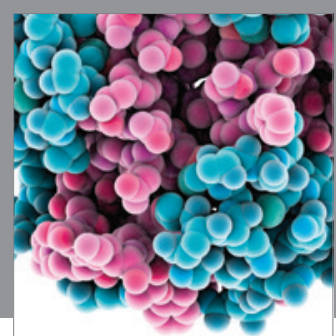

Journal of
Diabetes Research

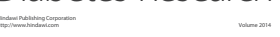

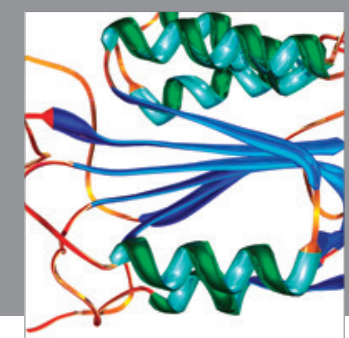

Disease Markers
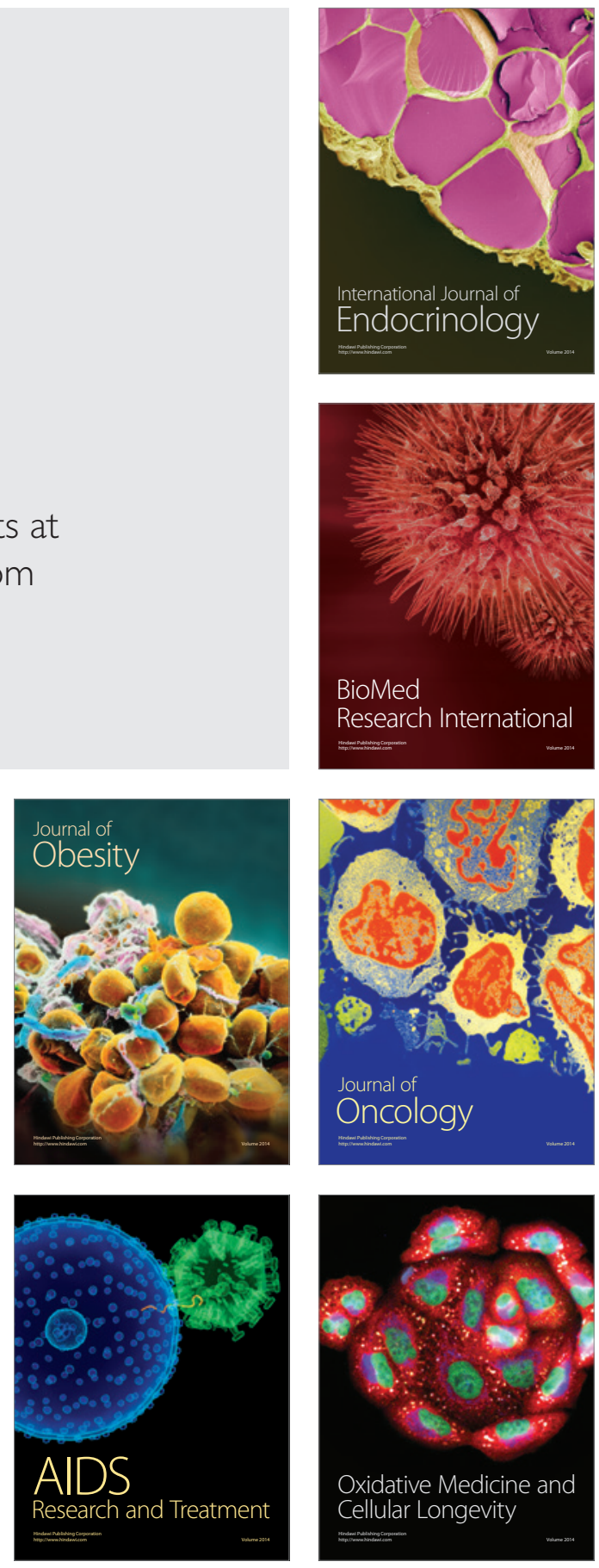